\title{
NOVOS HORIZONTES À GEOARTE
}

NEW HORIZONS FOR THE GEOART

\section{NUEVOS HORIZONTES PARA LA GEOARTE}

\author{
Júlio César Suzuki \\ Universidade de São Paulo, São Paulo, Brasil \\ Gilvan Charles Cerqueira de Araújo \\ Universidade de São Paulo, São Paulo, Brasil \\ Rita de Cássia Marques Lima de Castro \\ Universidade de São Paulo, São Paulo, Brasil
}

Em seu segundo número de 2021, a Revista Geografia, Literatura e Arte, da Universidade de São Paulo apresenta um rol de laços, pontes e horizontes temáticos diversificados. Para além da arte literária, há incorporação de estudos, análises, olhares e experiências voltadas para fotografia, cinema, pintura, poesia, história em quadrinhos, urbanidades e monumentos, exposições museais, além de contar com diferentes estudos geoarteliterários.

O papel da revista de promover, incentivar e contribuir para a divulgação destes debates é contínuo e se fortalece a cada nova publicação de suas edições. A arte e a espacialidade, por meio de diferentes diálogos, aproximações e partilhas pode ser observada ao longo dos artigos deste número. O aporto teórico e metodológico, bem como a diversidade e profundidade analítica e de aprofundamento de tais estudos poderão ser observados, lidos e experienciados.

Iniciamos este número da Geoliterart com o trabalho de Joaci Pereira Furtado, Falas de um monumento: O MAC Niterói no imaginário da cidade. Urbanidades, perscrutações museais e o papel do museu de Arte Contemporânea de Niterói são alguns dos objetivos e camadas de reflexões e análises apresentadas pelo autor. Em acréscimo a estes debates, há, de igual modo, a complexa relação entre a arte, o urbano e o próprio museu, convidando os leitores a partilhar de tais inquietações presentes no estudo apresentado. 
O artigo Nos passos de Jane Austen: o espaço literogeográfico nos romances austenianos é contribuição de Ana Cláudia Boavida Salgueiro da Silva, em que a espacialidade, como recurso criativo e de análise geoliterária, forma a base da sua discussão. Por meio de diferentes referenciais que tratam da obra de Jane Austin, há um convite para novos olhares, percepções e (re)descobrimentos das camadas narrativas da autora foco do artigo.

Em seguida, encontra-se o artigo "Ela canta, Pobre ceifeira": o território, a paisagem, o lugar e a crítica à modernidade, de Rodrigo Emídio Silva e Maria Geralda de Almeida. Neste estudo geopoético, os autores lançam mão de um rico e profundo arcabouço teórico e metodológico, envolvendo pilares da cultura, fenomenologia e questões existências nos estudos geográficos, com a promoção de análises geoliterárias sobre o poema de Fernando Pessoa e sua relação íntima com a espacialidade.

Mariana Vicente Oliveira, em seu Requadros e janelas: os olhos da cidade por Will Eisner, apresenta um estudo envolvendo elementos imagéticos, estilísticos, narrativos e criativos de Will Eisner em relação à nona arte. Por meio de um diálogo entre conceitos e categorias da Geografia e da arte sequencial dos quadrinhos, em singular estudo sobre novas possibilidades e olhares para a geoarte.

Em continuidade à temática da nona arte, temos o estudo realizado por Zidelmar Alves Santos, intitulado Entre a Foice e o Martelo: a representação da guerra fria em uma história em quadrinhos do Superman. Ensino de Geografia, quadrinhos, contexto geopolítico, econômico e cultural da Guerra Fria são alguns dos elementos que o autor faz amplo uso para efetuar as conexões, comparações, análises e perscrutações teóricometodológicas.

O fundamento geopoético de Gaston Bachelard é um dos principais fundamentos do artigo de Transcendência da palavra poética a partir do espaço paisagístico, de Natália Ferreira Santos e José Elias Pinheiro Neto. Em suas proposições, reflexões e análises, os autores realizam uma ponte entre tópicos e temas da literatura, subjetividades, poesia, ontologia fenomenológica bachelardiana e categorias de análise da Geografia, especialmente a paisagem.

No artigo de Leandra de Brito Rodrigues e Sidelmar Alves da Silva Kunz, intitulado Estudo da paisagem de Goiânia-GO: os bens culturais sob a perspectiva dos 
cidadãos, há diferentes perspectivas e olhares para a espacialidade urbana. A categoria geográfica paisagem é utilizada como aporte teórico e metodológico às problematizações dos autores em relação a identidades, narrativas, bens culturais e a complexidade e diversidade da capital goiana.

La geografía del desarraigo. una interpretación de la obra "The Grapes of Wrath" é o artigo de Carlos Enrique Castro Méndez, Júlio César Suzuki e Gilvan Charles Cerqueira de Araújo. A espacialidade e representações dos sujeitos no mundo representado no filme The Grapes of Wrath é o foco dos autores, no entremeio entre Geografia e a sétima arte, com elementos biográficos, ambientais, econômicos e sociais presentes no filme de 1939 .

Kauan Arthur Fonseca Lunardon é o autor do último artigo deste número, Entre utopias abstratas e concretas: cyberpunk, a Nova Babilônia e o espaço público contemporâneo. O autor faz amplo uso da Nova-Babilônia, obra do artista situacionista Constant Nieuwenhuys em suas análises, de forma interdisciplinar e dialógica, com conceitos e ideias sobre a urbanidade lefebvriana e de novas perspectivas para o cotidiano na cidade.

Na seção Expressões Geoarteliterárias, há os versos de León Denis Ferreira Xavier, Tire seus óculos, em que o autor convida o leitor a uma reflexão sobre a arte poética e nuances decoloniais e de novas visualidades e leituras históricas, culturais e sociais.

Em “O Cidadão do Mundo”: uma resenha sobre o documentário que ilustra a vida de Josué de Castro, de Sebastião Pinheiro Gonçalves Cerqueira Neto e Leonardo Thompson da Silva, há uma análise do importante papel dos estudos de Josué de Castro para o pensamento geográfico brasileiro, por meio de imagens, discursos, ideia e teorizações do autor.

Beira-Mar: reflexões sobre as geografias presentes nas pesquisas de Rachel Carson é a resenha Marcelo Correa Porto, em que se identifica uma geografia dos oceanos constituída na obra de Rachel Carson, por meio de sua riqueza técnica, natural, social e correlações com os estudos e temas da Geografia e sua premissa de olhar para o mundo entre a sociedade e natureza. 
Fechamos este número da Geliterart com a resenha Transformações do sertão paulista na pintura "O lavrador de café" de Cândido Portinari de Vitor Moretti Zonetti. O autor realiza um estudo interdisciplinar entre elementos geográficos, ontológicos e artísticos a partir da obra de Cândido Portinari e os interiores territoriais do estado de São Paulo.

Convidamos a todos para a leitura dos artigos deste número da revista que, expandindo seus horizontes da geoarte, apresenta uma diversidade e multiplicidade de estudos, olhares, experiências, teorias, métodos e análises geoarteliterárias.

Recebido em 08/12/2021.

Aceito em 08/12/2021.

Publicado em 15/12/2021. 